\title{
A HISTORICAL OVERVIEW AND ANNOTATED BIBLIOGRAPHY OF THE STUDIES ON THE ARABIC GRAMMATICAL TRADITION IN AL-ANDALUS ${ }^{\star}$
}

\author{
Francesco Binaghi \\ Université Sorbonne Nouvelle-Paris 3 \& Laboratoire d'Histoire des théories linguistiques \\ (UMR 7597), Paris, France
}

\section{Abstract}

Arabic grammatical studies in al-Andalus have never drawn much attention in the two fields of Arabic grammatical thought and alAndalus. However, a tradition of studies goes back to the beginning of the $20^{\text {th }}$ century and, after some notable contributions between the 1980 s and the 2000 s, it is now witnessing a renewal in interest and approaches.

The present historical overview and annotated bibliography of relevant research up until mid2018 aims at providing a comprehensive, chronologically organised state of the art, which will help to identify new trends and possibilities for further research, thus facilitating future contributions to this field.

\section{Keywords}

Arabic grammatical tradition, history of linguistic theories, al-Andalus, intellectual history, historical overview, annotated bibliography

\section{Résumé}

Les études grammaticales arabes en alAndalus n'ont jamais suscité beaucoup d'intérêt dans les domaines de la pensée grammaticale arabe et d'al-Andalus. Cependant, une tradition de recherche dans ce domaine remonte au début du $\mathrm{Xx}^{\mathrm{e}}$ siècle et, après des contributions remarquables entre les années 1980 et les années 2000, elle témoigne maintenant d'un renouveau d'intérêt et d'approches dans son étude.

L'aperçu historique et la bibliographie commentée que nous proposons ici, et qui couvre les résultats des recherches jusqu'à la moitié de 2018, offrent un état des lieux détaillé et organisé chronologiquement, dans l'espoir que ce travail pourra favoriser l'identification de nouvelles tendances et possibilités de recherche, en facilitant ainsi la contribution à ce champ.

\section{Mots-clés}

Tradition grammaticale arabe, histoire des théories linguistiques, al-Andalus, histoire intellectuelle, aperçu historique, bibliographie commentée

$\star$ This article is a revised and updated English version of the state of the art I had sketched in my $\mathrm{PhD}$ dissertation (Binaghi 2015). I would like to thank two anonymous peer-reviewers for their valuable comments and for pointing out a few Arabic references which had been unknown to me. 
Out of the 2209 biographies that al-Suyūṭi (d. 911/1505) dedicates, in the late biographical dictionary Buggyat al-wu'āt fì țabaqāt al-lugawiyyin wa-l-nuhāt, to learned men active in the fields of Arabic grammar and lexicography up to his time, at least 691 (i.e. more than 31\%) concern Andalusian scholars. ${ }^{1}$ Despite such a considerable statistical representation and the intense intellectual activity Andalusian authors showed throughout history, their contribution to the study and theorisation of Arabic grammar has long been neglected by Arabists, or at best taken into account only for a few original - and sometimes eccentricideas. This marginalisation can be explained by two main factors: a chronological one, as grammatical studies only started to thrive in al-Andalus in the $5^{\text {th }} / 11^{\text {th }}$ century, that is after what has generally been identified so far as the main period of theorisation and standardisation of the Arabic grammatical theory (chiefly $4^{\text {th }} / 10^{\text {th }}$ century); and a geographical one, as al-Andalus represents the far western border of the Muslim world, far away from those regions (mainly Iraq, Persia and the historic region of Syria) where the so-called standard theory had been elaborated.

From this perspective, I will mainly use the expression "Andalusian grammarians" to refer, in a rather broad way, to those learned men who meet the two following criteria: (i) whatever their origin and the place they settled, they either acquired their knowledge in al-Andalus, or settled and lived there for some time, hence interacting with local scholars; (ii) they were either renowned for being active in the field of Arabic grammar or, whatever their main filed of specialisation, they wrote at least one treatise dealing with Arabic grammar. ${ }^{2}$ The criterion for asserting whether a treatise belongs to the "Arabic grammatical tradition" might also be difficult to define unambiguously; however, we can quite safely include in this category all those treatises which either (i) explicitly deal with the description and/or theorisation of grammar, or (ii) present a sort of "applied grammar", such as a grammatical reading and analysis of a non-grammatical text (notably poetry, the Qur'an, and other religious texts).

The interest of compiling the present historical overview and annotated bibliography is twofold. First, it will allow to grasp the historical development of the studies on this regional subtradition of the Arabic grammatical thought and will provide the reader with a wider picture of the current situation. Second, the fact of bringing together material and references will enable interested scholars to identify gaps for further research. In this way, the present contribution would like to foster a more differentiated approach to the analysis of Andalusian grammatical texts,

1 The figure of 691 Andalusian scholars is drawn from the database Prosopografia de los Ulemas de al-Andalus, available at https://www.eea.csic.es/pua/ (accessed on 13 April 2018); see also Guardiola (1990, p. 218), who gives the figure of 738 .

2 See also Binaghi 2015, p. Xx-XXI. 
treating them not only as part of the main field of the Arabic grammatical tradition, but also as products of a specific subtradition deeply influenced by the region's historical context and strong cultural identity.

In order to meet these objectives, I thought it would be useful to include in this overview not only the works characterised by a proper linguistic approach, but also those dealing with the relationship and "technical" exchanges between language, grammar and other disciplines (e.g. literary or Qur'anic studies), as well as publications providing more general information on Andalusian grammarians both from a historical and/or biographical viewpoint. However, I have decided to include only the contributions which deal in a principal or more substantial way with Andalusian authors, leaving aside those that cite or approach their theories in a corollary way. ${ }^{3}$ Aiming to be as exhaustive as possible, I have identified around 130 items, which will be briefly introduced in the following pages.

\section{General REFERENCE WORKS}

Even though they do not deal specifically with the grammatical theories of Andalusian learned men, three fundamental reference works should be briefly mentioned here. ${ }^{4}$ Interestingly enough, they were published at the beginning of three (out of the four) periods sketched below ( $\S 2$ "The first studies on Andalusian grammarians"; $\S 4$ "The establishment of the field"; and $\S 5$ "Latest developments") and, thus, might have played a key role in the development of studies on the Arabic grammatical tradition in al-Andalus.

The first of these fundamental reference works is Carl Brockelmann's (18681956) Geschichte der Arabischen Litteratur (GAL), whose two original volumes (G) are published in 1898 and 1902, and the three supplement volumes (S) between 1937 and 1942. Brockelmann presents biographical and bibliographical information about authors from all fields of literature and scientific knowledge following a chronological and geographical arrangement. Hence, several sections (GAL, G I, p. 132-133, 308-313; G II, p. 259; S I, p. 202-203, 542-547; S II, p. 370-371) are dedicated to "philological" studies in Muslim Spain ("Die Philologie in Spanien").

In the late 1960s, Fuat Sezgin (1924-2018) starts publishing his Geschichte des arabischen Schrifttums (GAS), whose ninth volume, published in 1984, is entirely dedicated to Arabic grammar (“Grammatik") until circa 430 H (=1038-1039). He

3 As a matter of fact, the steady publication of new sources and the fact that some Andalusian authors are now very well known would have made it impossible to account for all works citing, here or there, an Andalusian grammarian.

4 I will not include in this section, however, the Encyclopaedia of Islam (EI), where short notices of Andalusian grammarians can also be found. 
organises grammarians according to geographical criteria too, ${ }^{5}$ and ch. VII presents the main Andalusian grammarians ("Grammatiker in Spanien") from the end of the $2^{\text {nd }} / 8^{\text {th }}$ century up to the mid $5^{\text {th }} / 11^{\text {th }}$ century (GAS, IX, p. 217-225). Sezgin's selection can also be taken as representative of the state of scholarship at his time.

The latest of these general reference works is the Biblioteca de al-Andalus, whose nine volumes are published between 2004 and 2012. This encyclopaedia presents a complete catalogue, arranged alphabetically, of Andalusian writers and learned men, whose biography and bibliography are exhaustively presented - despite some minor imperfections - and are supported by a rich list of primary and secondary sources. I invite the reader interested in learning more about the life and the writings of Andalusian grammarians and learned men cited in this paper to consult this very useful encyclopaedia.

\section{The first studies on Andalusian grammarians (1900-1960) ${ }^{6}$}

The first article dealing with an Andalusian grammatical text dates to the very beginning of the $20^{\text {th }}$ century and presents the grammar of "the language of Turks", the Kitāb al-'Idrāk li-lisān al-'Atrāk, of 'Abū Hayyān al-Ġarnāṭ̄ (d. 745/1344) (Bouvat 1907).

In the 1940s, Sydney Glazer's attention focuses on the 'Alfiyya of Ibn Mālik (d. 672/1274) (Glazer 1941a) and on its commentaries, notably the one by 'Abu Hayyān al-Ġarnāțī (Glazer 1941b and 1942); Glazer's interest for this latter text, al-Manhağ al-sālik, leads to the publication of its critical edition ('Abū Hayyān, Manhă̌).

In the 1950s, Roger Arnaldez publishes an analytical study on the relationship between grammar and theology in the thought of Ibn Hazm (d.456/1064), the founder of the Zāhirī legal and theological school (Arnaldez 1956). In the same years, an article on Luso-Arabic grammarians - that is to say grammarians born in the southern lands of today's Portugal ${ }^{7}$ - presents the life and the writings of the three most prominent of them: al-' A 'lam al-ŠSantamarī (d. 476/1083), Ibn al-Sīd alBaṭalyawsī (d. 521/1127) and Ibn al-Sarrāğ al-ŠSantarīn̄̄ (d.549/1154-5?) (Domingues 1958). Ibn Sīda (d.458/1066) also starts to be studied during this decade, although not for his grammatical writings: the focus is rather on his dictionary al-Muhașșas (Talbi 1956 and Cabanelas Rodríguez 1961).

5 Could we maybe see in Brockelmann's and Sezgin's geographical arrangements a borrowing from medieval Arabic biographical sources such as, for instance and as far as grammar is concerned, the Țabaqāt al-nahwiyyin wa-l-lugawiyyin of al-Zubaydī (d. 379/989)?

6 Dates in the sections' title are approximate and simply aim at providing a broad periodisation.

7 The region called $\dot{G}$ arb al- ${ }^{-}$Andalus by medieval Arabic geographers and historians; $\mathrm{cf} E I^{2}$, art.

"Gharb al-Andalus". 
While Arabists, during this first period, seem to be more concerned with individual grammarians or grammatical texts, Arab scholars ${ }^{8}$ approach the Andalusian grammatical movement as part of the more general Arabic grammatical tradition and discuss whether Andalusians formed a proper "grammatical school" on the model of the pretended "grammatical schools" of Bașra and Kūfa (Ṭantāwī 1938; 'Afg̈ānī 1951 and 1957). This wider but, at the same time, more traditional approach can be better understood if we consider the fact that the medieval Arabic grammatical tradition (including its historiography) has influenced the development of grammatical studies in the Arab world until today.

\section{A GROWING INTEREST (1960-1980)}

Starting from the second half of the 1960s, Andalusian grammarians are the subject of a steadier number of works. Throughout the following twenty years, research is mainly carried out in the Arab world.

During this second step, the traditional approach is still very much present and, for instance, the question of "grammatical schools" and the place of al-Andalus within them is discussed again by Dayf (1968). At the same time, we also find the first attempts to study the development of grammatical and lexicographical studies in al-Andalus in a more specific and organic way. Albert Mutlak focuses on the first four centuries of the Muslim presence in the Iberian Peninsula $\left(2^{\text {nd }}-5^{\text {th }} / 8^{\text {th }}-11^{\text {th }}\right.$ centuries) and presents not only the history of some linguistic concepts, as well as the learned men and their work, but also the place of linguistic studies in the Andalusian society and their relationship with other disciplines (Mutlaq 1967). Mutlak's work is later somehow continued by Tayyār (1980), who focuses on the Almoravid and Almohad periods $\left(5^{\text {th }}-7^{\text {th }} / 11^{\text {th }}-13^{\text {th }}\right.$ centuries $)$ but mainly deals with lexicography. These two studies, however, deploy a rather historical than linguistic approach. A more linguistic treatment, on the contrary, is proposed by 'Amīn 'Alī al-Sayyid (1964), who tries to evaluate the role played by Andalusian grammarians and grammatical texts in the development of grammatical studies in the Islamic East throughout the late medieval period, and by Haytī (1975), who presents the grammatical theories of the main Andalusian authors of the $6^{\text {th }}-7^{\text {th }} / 12^{\text {th }}-13^{\text {th }}$ centuries.

8 Throughout this article, I generally use the terms "Arabists" and "Arab scholars" to identify works carried out, respectively, outside the Arab world and within it. As a matter of fact, different trends and concerns can sometimes be noticed, which is probably the result of different cultural backgrounds influencing scholars: in the Arab world, studies on Arabic grammar generally follow the medieval Arabic grammatical tradition approach and perspectives, whereas scholars working on Arabic grammar outside the Arab world tend to show a greater integration of modern linguistic theories and methods in their studies. 
Nevertheless, most works from this period consist in a bio-bibliographical study of a specific grammarian. That is the case, in the chronological order of the studies, for 'Abū Ḥayyān al-Ġarnāṭī (Hadīịi 1966), 'Abū Ğa far al-Lablī (d. 691/1291) (Māğid 1969), 'Abū Bakr al-Zubaydī (d. 379/989) ('Azzāwī 1975a), Ibn al-Sīd alBațalyawsī ('Abū Ğanāh 1977), and Ibn al-Ṭarāwa (d. 526/1132 or 528/1134) (Bannā 1980). This same approach is adopted in Spain by Cabanelas Rodríguez (1966) in his study on Ibn Sīda.

Some works also deal with a grammarian through the analysis of one of his treatises: Ibn Hišām al-Lahmī (d. 577/1182) and his commentary on the probative quotations (̌̌awāhid) of Sībawayhi's (d. 180/796?) Kitāb (Mațar 1974); 'Abū Bakr alZubaydī and his Istidrāk 'alā Sïbawayhi, a critical commentary of the Kitāb ('Azzāwī 1975b); 'Abū al-Faḍl al-Ṣaffār (d.after 630/1233) and his commentary of Sībawayhi's Kitāb (Sayyid, 'Ahmad 1979); Ibn al-Ṭarāwa and his commentary of al-Fārisī’s (d. 377/987) 'İ tafsìr Kitāb Sỉbawayhi, also a commentary of Sĩbawayhi's treatise (Qawzī 1987). Beside these published works, it is also possible to mention some $\mathrm{PhD}$ dissertations, as those by Ša 'bān (1972) and Shareef (1972) which present the critical edition of, respectively, the Šarh 'abyāt al-Ǧumal of al-'A 'lam al-Šantamarī and al-Käfiya alšăfiya of Ibn Mālik, including a rather developed study of the grammatical method applied by the two authors. We notice that a good number of these texts are actually commentaries on Sỉbawayhi's Kitāb, the earliest extant treatise in the history of Arabic grammar. The evaluation of the legacy of this prominent text in al-Andalus and the Maghreb is the object of two articles by Fāsī (1974) and Ḥağğì (1974).

As a matter of fact, only a few Andalusian Arabic grammatical treatises had been edited before Ša 'bān's and Shareef's dissertations, that is to say until the 1960s. These are: the Kitāb al-'Af'āl of Ibn al-Qūtịya (d. 367/977); the Kitāb al-Wādih fì al-nahw and the Kitāb al-Istidrāk 'alā Sïbawayhi fi kitāb al-'Abniya wa-l-ziyādāt of 'Abū Bakr al-Zubaydī; the 'Amālī of al-Suhaylī (d. 581/1185); the Kitäbal-Radd 'alā al-nuhāt of Ibn Maḍā' (d. 592/1196); the 'Alfiyya of Ibn Mu'țī (d. 628/1231); the 'Alfiyya and the Lamiyyat al-'af'äl of Ibn Mālik; the commentaries to these two latter treatises by Ibn Mālik's son Badr al-dīn Ibn al-Nāẓim (d. 686/1287); the Tashìl also by Ibn Mālik; the Manhağ al-sālik (commentary of Ibn Mālik's 'Alfiyya, as mentioned earlier) and the Kitāb al-'Idrāk li-lisān al-'Atrāk of 'Abū Hayyān alGarnățī (known until then as al-' Andalusī). The shortage of available texts largely contributes to explain the mainly biographical nature of the works from this period.

The few studies that propose a closer analysis of the grammatical thought focus on a small handful of treatises. Beside Ibn Mālik's and 'Abū Hayyān's writings, we witness, since the 1960s, a growth in interest for the work of Ibn Maḍā', who opposes some of the key principles of the grammatical theory established by his predecessors and seems, henceforth, to totally break up with the grammatical 
tradition. Such a "revolutionary" and "anticonformist" attitude made him a prestigious ancestor and a legitimation basis for all those who advocate, especially nowadays, a simplification of Arabic grammar. ${ }^{9}$ In only two decades, eight studies are published on Ibn Maḍā': 'Umar (1967), 'Īd (1973), Nakamura (1974), Ramón Guerrero (1984), Wolfe (1984), Molina Rueda (1987), Sarțāwī (1988), and again Wolfe (1990).

It is also in the 1970s and 1980s, starting with Ša 'bān's and Shareef's editions, that we notice a significant growth in the number of edited texts. During these two decades, the following treatises are published: ${ }^{10}$ the two commentaries of al-'A 'lam alŠantamarī on Sỉbawayhi's Kitāb; the works of Ibn al-Sīd al-Bațalyawsī, notably his two commentaries on the Ğumal of al-Zağğăğ̄̄ (d. 337/949); the Natājiğ al-fikr fi alnahw and the Masā'il fi al-nahw wa-l-lugia wa-l-hadit wa-l-fiqh of al-Suhaylī; the Muqaddima of al-Ğazūlī (d. 607/1210 or 610/1213 or 616/1219); the Tawți'a fi al-nahw of 'Abū 'Alī al-Šalawbīn (d.645/1247); the works of Ibn 'Ușfür (alMuqarrib, Mutul al-Muqarrib, al-Mumti fì al-tașrïf, and Šarh Ğumal al-Zağǧăğī); other treatises by Ibn Mālik and 'Abū Hayyān; and al-Mulahhas fí dabt qawānīn al'arabiyya and the Šarh al-Ğumal, called al-Basiț, of Ibn 'Abī al-Rabī' (d. 688/1289).

The consequence of this important activity of text edition is the remarkable growth, especially starting from the 1980s, of research and publications on Andalusian grammarians. I have to point out, however, that this growth (both in text edition and studies) corresponds to a more general trend concerning the whole of the Arabic grammatical tradition, and that works on Andalusian grammarians statistically remain a small minority.

\section{The establishment of THE Field (1980-2010)}

As we have seen, the majority of works on Andalusian grammarians produced until the end of the 1970s are the work of Arab scholars. Since the 1980s, more and more Arabists start turning their attention to the Andalusian tradition. ${ }^{11}$

9 Concerning the movement calling for a simplification of Arabic grammar, see e.g. Dayf (1986).

10 Unfortunately, the quality of these editions is uneven. I must also point out the difficulty to learn about (and even more to get hold of) new editions because of the fragmented situation of the publishing sector in the Arab world. This circumstance makes even more apparent the importance of review works on text edition such as the one by Weipert (2002) and the series of articles "Textes arabes anciens édités en Égypte" published in the Mélanges de l'Institut Dominicain d'Études Orientales (started in 1957 by Georges Chehata Anawati and continued since 1989 by Claude Gilliot).

11 Among the works on Ibn Madāa mentioned in the previous section, four out of the five produced by Arabists actually date between 1984 and 1990. I have nevertheless decided to present them earlier in order to try and bring together works dealing with the same author and having a more or less similar approach. 
Studies from this period show different tendencies. The main one is marked by a historiographical approach to the field of grammatical knowledge-which correspond, as a matter of fact, to the dominant historiographical trend in the study of all the aspects of al-Andalus. Some works take the form of a biobibliographical presentation of a given grammarian: that is the case with Ibn 'Abd al-Nūr (d. 702/1302) (Vélazquez Basanta 1987-1988), Ibn Mu'țī (Demir 2002) and al-Rabāḥ̄ (d. 358/969) (Deheidel 2002). Other works deal with the biography of a learned man in connection either with the history of a town - Ibn Sīda and Dénia (Epalza 1981), al-Suhaylī and Fuengirola (Arias 2008) - or with a historical period - Ibn al-Sīd al-Batalyawsī and the period from the mulük al-țawā'if until the Almoravids (Serrano 2002), al-Šalawbīn and the Almohad epoch (Rodríguez Gómez 1992).

A second tendency concerns the sociologic analysis of Andalusian grammarians another approach very much exploited during the 1980 s and the 1990 s. ${ }^{12}$ Four studies adopt this perspective and analyse the scientific journeys and migrations, the cultural centres in al-Andalus, the grammarians' social status and professions, as well as their production. The first work (Peña Martín 1991) covers the period of the $5^{\text {th }} / 11^{\text {th }}$ and the first half of the $6^{\text {th }} / 12^{\text {th }}$ centuries, that is to say the period of the mulük al-tawa $\bar{a}^{\prime} i f$ and the Almoravid epoch. This is followed by a second article (Arias 1995a) covering the second half of the $6^{\text {th }} / 12^{\text {th }}$ and the $7^{\text {th }} / 13^{\text {th }}$ centuries, that is the Almohad period. Two other studies (Peña Martín and Arias 1993 and 2009) focus more precisely on Arabic grammarians in the city of Malaga: beside a sociological analysis, they also offer a periodisation of the evolution of language-related studies and an analysis of the cultural role played by Malaga within al-Andalus.

Scholars' interest also aims at the study of the relationship between language and philosophy (including, notably, logic). The key figure in this respect is Ibn al-Sìd alBatalyawsī, first known and studied as a philosopher before the regard is also turned towards his literary and grammatical activity. Publications focus on his life (Serrano 2008) and, within his writings, on logic (Elamrani-Jamal 1979 and 1983), on dialectics (Elamrani-Jamal 1985), on the influence of al-Fārābī (d. 339/950-951) on his thought (Ramón Guerrero 1995 and Elamrani-Jamal 1996), and on the relationship between 'adab and falsafa (Urvoy 2005). In the field of logic and grammar, two book chapters are also dedicated to Ibn Rušd (Averroes, d. 595/1198) (Elamrani-Jamal 1990 and Hamzé 2002).

Concerning the history of the Arabic grammatical tradition, some works deal with the transmission of grammatical knowledge and of grammatical texts. Humbert (1994 and 1995), through the analysis of the manuscripts of Sỉbawayhi's

12 In the more general field of the Arabic grammatical tradition, it is possible to mention, for example, an analysis of the grammarians' professions (Versteegh 1989). 
Kitāb, underlines the role played by Andalusian grammarians in the preservation and continuation of the Kitäb's textual tradition. Peña Martín (2005a) and Grand'Henry (2010) investigate the figure of 'Abū 'Alī al-Qālī (d. 356/967) as transmitter, in Cordoba, of the grammatical method developed in Baghdad. In this group, one could also mention Larcher's (1996) review of the edition of Ibn Mālik's Tashil, where the nature and the textual history of this treatise is briefly sketched.

As it was mentioned earlier, the peculiarity of Ibn Maḍā's grammatical theories have raised particular interest because they quite clearly stand out from the Arabic grammatical tradition. In the same way, the Arabic grammars of Turkic languages have attracted the attention because of their originality. The most important among them is certainly the Kitāb al-'Idrāk li-lisān al-'Atrāk of 'Abu Hayyān al-Garnāṭ̂̄ (Ermers 1990, 1995 and 1999; Lancioni 1996). ${ }^{13}$

A more philological approach is deployed in studies on the oeuvre of Ibn al-Sīd al-Bațalyawsī (Peña Martín 1987 and 2007), on the grammatical method applied in the analysis of the questions of synonymy by al-Suhaylī and al-Šarīši (d. 619/1223) (Arias 1995b) and of proper names by al-Suhaylī (Arias 1996), on the lexicographical project of Ibn Sīda (Serrano Niza 1999), as well as on the question of probative quotations (šawāhid) in Ibn Harūf's (d. 609/1212) works (Peña Martín 2005b).

Some scholars also present linguistic studies of the theories expressed by Andalusian grammarians. Ditters (1985) analyses 'Abū Hayyān's conception of the mașdar noun phrase. The thought of Ibn al-Sīd al-Bațalyawsī is once more abundantly studied by Peña Martín: he analyses his conception of sentence (Peña Martín 1993-1994), of linguistic sign (Peña Martín 2004), and of time and tenses (Peña Martín 2006). Baalbaki shows the importance given by al-Suhaylī to macnā within the theory of 'amal, a theory underlying the conceptual organisation of Arabic grammar, whose modification or different implementation would result in important implications for the grammatical analysis (Baalbaki 1999; reviewed and completed in Baalbaki 2008, p. 290-297). Larcher investigates the categories of habar and 'inš $\bar{a}$ ' as they are employed in Ibn Mālik's Tashīl (Larcher 2011).

Finally, reference should also be made to the German commented translation of two chapters ('inna wa-'ahawātu-hā and al-mawșül) of the Manhağal-sālik of 'Abū Ḥayyān al-Ġarnāṭī (respectively in Bergter 1988 and Gille 1995).

While Arabists mainly work, as we have just seen, on specific topics, Arab scholars from this period adopt a larger view. Hence, a good number of studies, notably monographs, try to embrace both the presentation of a grammarian and the analysis of his grammatical ideas and method; however, some of these studies 
persevere in a rather bio-bibliographical approach. Many grammarians are investigated: 'Abū 'Alī al-Qālī (Rašīd 1982-1986; Wadgīin̄i 1978 and 1983), alĞazūlī (Zawāwī 1984), Ibn Sīda (Nu aymī 1984), al-Suhaylī (Bannā 1985), Ḩațțāb al-Māridī (d. after 450/1059) (Šā ir 1988), 'Abū al-Ḥasan al-'Ubbad̄ī (d. 680/1281) ('Abd al-Ǧawwād 1991), Ibn Ḥarīq al-Balansī (d. 622/1125) (Ibn Šarīfa 1996), Ibn Ṭalḥa (d. 618/1221) (T́ubaytī 1998), 'Abū Ḥayyān al-Ġarnāṭ̄i (Huațīb 1999), Ibn alSīd al-Bațalyawsī (Muhyī al-dīn 2001), Mālik b. al-Muraḥhal (d. 699/1300) (Ğubrān 2005), Ibn Mālik (Nağīb 2005), 'Abū 'Alī al-Qālī (Yāg̣ī 2008), and Ibn al'Ahụar al-'Išbīlī (d. 514/1120) (Nağğār 2009).

Another major approach of Arab research in this period is the study of a treatise and/ or of its commentaries. That is mainly the case of Ibn Mālik's 'Alfiyya: a monograph is dedicated to the contrastive analysis of this didactic poem with the 'Alfiyya of Ibn Mu'țī (Ğubūrī 1991), whereas three other books discuss the commentaries of Ibn Mālik's 'Alfiyya (Rāğihịi 1980, Mursī 1987, and Nağìb 2000). It is also possible to include in this category: an article on al-Suhaylī's grammatical approach in his 'Amāli (Ğanābī 1984) and a research into language-focused remarks in his al-Rawd al-'unuf, a commentary of the Prophet's biography (Ša 'bān, Ḥāmid 1984); a study on the grammatical approach to the analysis of the Qur' an in 'Abū Hayyān al-Garnāțī's tafsìr (Sayyid, Sabrī 1989); a PhD dissertation on Ibn Sīda's commentary of the šawāhid in al-Zağğăğḡ's Ğumal, which includes the edition of the text ('Āmūdī 1990); a study on Ibn Malkūn (d. between 580/1184 and 584/1188) and his methodology through the analysis of the manuscript of his 'Ị̇āh al-minhağfí al-ğam' bayna kitābay al-Tanbìh wa-l-Mubhağ (Ǧīīi 2002); and an anthology of some passages of three Andalusian commentaries - those of al-Zubaydī, Ibn Ğandal (d. 401/1011) and al'A 'lam al-Šantamarī - on Sỉbawayhi's Kitāb (Dannā' 2003).

Other publications deal with a specific aspect of the grammatical activity of a grammarian, such as al-Rabāḥī and the importance of his journey to Egypt for the establishment of linguistic studies in al-Andalus (Hiğāzī 1995), and Ibn 'Uṣfür and his contribution to Arabic morphophonological studies (Qabāwa 1999).

Finally, beside three studies on the cultural life in al-Andalus in which the grammatical activity is also presented (Bišrī 1997, Bišrīi 1993, and 'Arīnī 1995), ${ }^{14}$ two works focus more closely on the history of Arabic grammatical studies in alAndalus. The first one sketches out the development of grammatical studies during the $5^{\text {th }} / 11^{\text {th }}$ century and presents the main grammarians and their most significant treatises (Tubayti 1996). The second one does the same for the $6^{\text {th }}-7^{\text {th }} / 12^{\text {th }}-13^{\text {th }}$ centuries, but also includes a presentation of some aspects of the grammatical thinking from these two centuries (Yahyyāwī 2011). 
A peculiarity of the interest for the Andalusian grammatical tradition in the Arab world is that it finds a fertile ground among Master and PhD students, and hence results in a good number of dissertations from which are issued some of the titles mentioned earlier. These dissertations often consist, also, in the edition of grammatical texts. This is particularly important since a dozen of treatises that had not been edited earlier are now available in an edited form: the Šarh 'abyāt alĞumal of Ibn S̄̄da; the Šarh risālat Ibn Harīq fí šarh 'abyāt al-Ǧumal of al-Bayyāsī (d. 653/1255); the al-Mabāḥ̂țal-kāmiliyya fíšarh al-Muqaddima al-Ğazūliyya of Ibn al-Muwaffaq al-Lurqī (d. 661/1263); the Šarh al-Ǧumal of Ibn al-Ḍā' i ' (d. 680/1281); the Šarh al-Ǧazūliyya of al-'Ubbadī; the al-Muntahab al-'akmal 'alä kitāb al-Ǧumal of al-Haffāf al-' Anșārī (d. second half of the $7^{\text {th }} / 13^{\text {th }}$ century); the Šarh Ǧumal alZağğăğ̄i of al-Ġāfiqī (d. 716/1317); the Šarh 'Alfiyyat Ibn Mu'ți and the Šarh 'Alfiyyat Ibn Mālik of Ibn Ğābir al-Hawwārī ${ }^{-15}$ (d. 780/1378); the Taqyìd 'alā ba'd Ğumal alZağğḡăğ of Ibn Lubb al-Ġarnāțī(d. 782/1381); the al-'Ağwiba al-murdiya 'an al-'as' ila al-nahwiyya and the 'Unwān al-'ifäda li-'ihwwān al-istifāda (a commentary of the 'Āğurrūmiyya) of al-Rā'i (d. 853/1450). ${ }^{16}$

As already stated in the introduction, I have only presented here those works which deal, in an extensive way, ${ }^{17}$ with Arabic grammarians either of Andalusian origin or having played a role in the evolution of grammatical studies in alAndalus. However, these references cannot be exhaustive, as some grammarians are also often cited in other works as corollary or supporting references. ${ }^{18}$

\section{LATEST DEVELOPMENTS (2011 ONWARD)}

Almost all of the works cited so far could be summed up in two main groups: those that approach Andalusian grammarians as part of the Andalusian cultural milieu, thus not analysing linguistic theories in detail; and those that, on the contrary, analyse grammatical theories as part of the Arabic grammatical tradition, but not giving due account of the specificity of the Andalusian cultural milieu.

15 The editor of the Šarh 'Alfiyyat Ibn Mu'ți actually attributes the treatise to 'Abū Ğa far 'Ahmad b. Yūsuf b. Mālik al-Ru'aynī (d. 779/1378), while Ibn Ğābir, his travelling companion, seems to be the true author.

16 Most of these texts are now available online in a scanned form. I have not included in this list the dissertations presenting the edition of a text which had already been edited earlier.

17 The only exception being Baalbaki (2008), dedicated to the legacy of Sỉbawayhi's Kitāb, which has been mentioned because some pages continue and complete a previous work on the Andalusian al-Suhaylī (Baalbaki 1999).

18 For example, Deheidel (2003) discusses the principle of grammatical justifications ( ${ }^{\text {ilal }) \text { and }}$ presents its history since the beginnings of Arabic grammar until its reception in the $20^{\text {th }}$ century. In the article, the author also mentions the conception of cilal among some Andalusian learned men: Ibn Hazm, Ibn Maḍā', Ibn Huarūf and 'Abū Ḥayyān al-Ġarnāṭ̂̄ (p. 100-101). Because of the small place accorded to these authors, however, this article has not been included in the bibliographical overview. 
In 2011, Michael Carter publishes an article whose title is very evocative: "The Andalusian Grammarians, are they different?" The author gathers some particular elements of this subtradition of Arabic grammatical studies: deviant personal attitudes and features of the grammarians themselves; different working and learning methodologies; and especially innovative or alternative analysis of some grammatical points. At the end, he asks the question whether all of these peculiarities are the result of a specificity of the cultural environment which influenced the development of grammatical studies as compared to the Islamic East. Hence, he is the first one who strongly argues for the need for a different approach in the study of the Andalusian Arabic grammatical tradition.

A few years later, two PhD dissertation are completed. In 2015, Binaghi presents a study on the history and the diffusion of the Kitāb al-Ğumal fi al-naḥ of 'Abü alQāsim al-Zağğăğī. This originally eastern book, yet largely neglected in the Islamic East, quickly becomes the most popular textbook of Arabic grammar in al-Andalus and, from there, it spreads to North Africa through Andalusian networks and migrations. As the Ǧumal almost becomes a symbol of Andalusian identity, the study of its commentaries contributes to our appreciation of the Andalusian grammatical approach.

In 2016, Campanelli submits a study on - and including an Italian translation of the Kitāb al-Radd 'alà al-nuḥāt of Ibn Maḍā'. Almost three decades after Wolfe's work, which contributed to a better understanding of the textual history of the Radd, Campanelli proposes a reinterpretation of some aspects of Ibn Maḍā's thinking which show an influence of previous grammarians (especially Küfan) on this author. The results of her investigation highlight a less revolutionary method than previously thought. ${ }^{19}$

Other publications having appeared in the last few years deal with different topics. In relation to the Zāhirī school, Versteegh (2013) evaluates the influence of the Zāhirī theological thought on Ibn Maḍā's grammatical views, whereas Peña Martín (2013) analyses Ibn Hazm's attitude towards the grammatical theory and practice. Al-Suhaylī is studied by Šāwiš (2013), who provides an in-depth investigation of his treatise Natā'iğ al-fikr, and by Kasher (2016), who highlights the importance of iconicity (i.e. the correspondence between form and meaning) in al-Suhaylīs works and shows to what extent this concept underpins his grammatical theory. Ibn Sīda is also the subject of two articles: Buendía (2015) examines the vocabulary relating to sex within al-Muhasssas and reconstructs Ibn Sīda's discourse about sexuality, whereas Grande (2017) discusses Ibn Sīda's notion of $b \bar{a} b$ and draws a parallelism between his theory and the contemporary notion of semantic field. Finally, Yāsīn's book (2015) studies $6^{\text {th }}-8^{\text {th }} / 12^{\text {th }}-14^{\text {th }}$ 
century Andalusian grammatical thinking with reference to the influence of the Zāhirī theological thought, the relationship with Qur'anic exegesis, and the approach to some central principles of the grammatical theory.

For long decades, studies on the Arabic grammatical thought in al-Andalus have been marginal within the main fields of both the Arabic grammatical tradition and al-Andalus. Nevertheless, recent research - which, it should not be forgotten, is the result of a long tradition of studies dating back to the beginning of the $20^{\text {th }}$ centuryhas shown that this area of studies can be very fruitful and can largely contribute to our knowledge and understanding of the history of linguistic theories in the Arab world on the one hand, and of the cultural and intellectual history of al-Andalus on the other hand. Accordingly, it could open new paths for research, and some projects, as the one presented by Cassarino and Ghersetti (2017), are seeing the light of the day. ${ }^{20}$ It is only to be hoped that they will be followed by researchers.

\section{BIBLIOGRAPHY}

\section{Primary Sources}

'Abū Hayyān = Abû-Hayyân Muhammed İbn Yusuf, 1931. Kitâb al-İdrâk li-lisân al-Atrâk, ed. Ahmet Caferoğlu, Istanbul, Evkaf Matbaası.

'A bū Hayyān al-'Andalusī, 1404-1409/1984-1989. Irtišāa al-darab min lisān al-'arab, ed. Mușțafā 'Aḥmad al-Nammās, Cairo, Maktabat al-Hānğì, 3 vol.

'Abū Ḥayyān, Manhağ = 'Abū Hayyān Muhammad b. Yūsuf b. 'Alī al-Ġarnāṭ̂̄ al'Andalusī, 1947. Manhă̌ al-sālik fì al-kalām 'alā 'Alfiyyat Ibn Mālik, ed. Sidney Glazer, New Haven, American Oriental Society.

'Abū Hayyān al-naḥwī al-'Andalusīi, 1402/1982. Al-Mubdi' fí al-tașrî́f, ed. 'Abd al-Hamīd al-Sayyid Talab, Kuwait, Maktabat dār al-'urūba li-1-našr wa-1-tawzī' .

'Abū Hayyān al-naḥwī al-'Andalusī al-Ġarnāțī, 1405/1985. Al-Nukat al-ḥisān fi šarh Ġāyat al-ihhsān, ed. 'Ảbd al-Husayn al-Fatlī, Beirut, Mu' assasat al-risāla.

'A bū Hayyān Muhammad b. Yūsuf al-Ġarnāțī al-'Andalusīi, 1406/1986. Tad̄kirat al-nuhāât, ed. 'Afîf 'Abd al-Raḥmān, Beirut, Mu' assasat al-risāla.

'Abū Hayyān Muhammad b. Yūsuf b. 'Alī al-naḥwī, 1407/1987. Al-Tadrīb fí tamtīl alMuqarrib, ed. Nihād Fulayh Hasan, Baghdad, Maṭba at al-'iršād.

'Abū Hayyān al-' Andalusī, 1402/1982. Taqrīb al-Muqarrib, ed. 'Afîf 'Abd al-Raḥmān, Beirut, Dār al-masīra.

'A 'lam al-Šantamarī (al-), 'Abū al-Hağğāğ Yūsuf b. Sulaymān b. 'Īsā, 1407/1987. Al-Nukat fì tafsìr Kitāb Sỉbawayhi, ed. Zuhayr 'Abd al-Muḥsin Sulțān, Kuwait, Ma'had almahtūtāt al-'arabiyya, 2 vol.

'A 'lam al-Šantamarī (al-), 'Abū al-Hağğăğ Yūsuf b. Sulaymān b. 'İsā, 1992. Tahṣil 'ayn aldahab min ma'din ğawhar al-'adab fí 'ilm mağāzāt al-'arab, ed. Zuhayr 'Abd al-Muhsin Sulțān, Baghdad, Dār al-šu'ūn al-țaqāfiyya al- 'āmma.

20 After the panel at the 28th Conference of the Union Européenne des Arabisants et Islamisants (Palermo, 12-15 September 2016) mentioned in the article, other scientific meetings have been organised: two study days in Catania (4-5 April 2017), a workshop at the Fourteenth International Conference on the History of The Language Sciences (Paris, 28 August-1 September 2017), a symposium in Venice (15-16 November 2017), and a panel at the Fifth World Congress for Middle Eastern Studies (Seville, 16-20 July 2018). 
Badr al-dīn Ibn al-Nāzim, 'Abū 'Abd Allāh Muhammad b. Muhammad Ibn Mālik, 1312 H [= 1894-1895]. Šarh ’Alfiyyat Ibn Mālik, ed. Muhammad b. Salīm al-Labābīd̄̄, Beirut, Matba at al-Qiddīs Ḡāwurğiyūs.

Badr al-dīn Ibn al-Nāẓim, Šarh Lāmiyyat Ibn Mālik= Badraddîn, 1866. Ibn Mâlik's Lâmîyat al Af'âl mit Badraddîn's Commentar, ed. Wilhelm Volck, Leipzig, in Commission bei Leopold Voss.

Bayyāsī (al-), Abū al-Hağğāğ Yūsuf b. Muhammad b. 'Ibrāhīm al-'Anșāīī, 1421 H [=2000-2001]. Śarh Risālat Ibn Harìq (unpublished), ed. 'Abd Allāh b. Muhammad alSulaymān̄i, Master Dissertation, Mecca, Gāmi 'at 'Umm al-qurā.

Ġāfiqī (al-), 'Abū 'Isḥāq 'Ibrāhīm b. 'Ahmad, 1416/1996. Šarh Ğumal al-Zağğāğì (unpublished), ed. Hamūd b. 'Utayq b. Răḍī al-Ma badī al-Ḥarbī, Master Dissertation, Mecca, Ğāmi at 'Úmm al-qurā.

Ğazūlī (al-), 'A bū Mūsā 'Īsā b. 'Abd al- 'Azīz, 1408/1988. Al-Muqaddima al-ğazūliyya fí al$n a h w$, ed. Ša'bān 'Abd al-Wahhāb Muhammad, Cairo, Maṭba 'at 'Umm al-qurā.

Haffāf (al-), Muhammad b. 'Aḥmad b. 'Abd Allāh al-'Anșārī al-' Išbīlīi, 1412/1991. Al-Sifr al-țālițin al-Muntahab al-'akmal 'alā kitāb al-Ǧumal (unpublished), ed. 'Aḥmad Būyā Walad al-Šayh Taqī al-dīn, Ph.D. Dissertation, Mecca, Gāmi at 'Umm al-qurā, 3 vol.

Ibn 'Abī al-Rabīi', 'Ubayd Allāh b. 'Ahmad b. 'Abd Allāh al-Qurašī al-'Išbīlī al-Sabtīi, 1407/

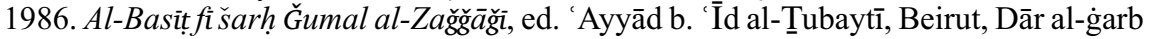
al-'islāmī, 2 vol.

Ibn 'Abī al-Rabī' ', 'Abū al-Husayn 'Ubayd Allāh b. 'Abī Ğa 'far 'Aḥmad al-Qurašī, 1405/ 1985. Al-Mulahhas fí dabṭ qawānīn al-'arabiyya, ed. 'Alī b. Sultạn al-Hakamī, Medina, s.n.

Ibn al-Ḍā'i i', Šarh al-Ğumal, vol. 1 = Badrawāy (al-), Yahyā 'Alwān, s.d. Ibn al-D̄à'ic wa'ațaru-hu al-nahwĩ ma'a tahqĩq wa-dirāsat al-qism al-'awwal min šarhi-hi li-Ğ́umal alZağğăği (unpublished), Ph.D. Dissertation, Cairo, Ğāmi 'at al-'Azhar.

Ibn al-Ḍā'i', Šarh al-Ǧumal, vol. 2 = Ibn al-Ḍā'i', 'Abū al-Hasan 'Alī b. Muhammad al'Išbīlīi, s.d. Al-Qism al-țānì min Šarh al-Ǧumal al-kabìr (unpublished), ed. Nàdī 'Abd alĞawwād, Ph.D. Dissertation, Cairo, Ğāmi 'at al-'Azhar.

Ibn Ğābir, Muḥammad b. 'Aḥmad b. 'Alī al-Hawwārī, 1410/1990. Šarh 'Alfiyyat Ibn Mālik (unpublished), ed. 'Abd Allāh b. 'Abd al-Raḥmān al-Muhawwas, Ph.D. Dissertation, Riyadh, Ğāmi 'at al-'imām Muḥammad b. Sa 'ūd al-'islāmiyya, 4 vol.

Ibn Ğābir, Śarh 'Alfiyyat Ibn Mu'țì = Ru 'aynī(al-), 'Abū Ğa 'far 'Ahmad b. Yūsufb. Mālik, 1414/ 1994. Šarh 'Alfiyyat Ibn Mu'ți (unpublished), ed. Hasan Muhammad 'Abd al-Raḥmān 'Ahmad, Ph.D. Dissertation, Mecca, Gāmi' at 'Umm al-qurā, 2 vol.

Ibn Lubb, 'Abū Sa īd Farağ b. Qāsim, 1405-1406/1985-1986. Taqyìd Ibn Lubb calā bacd Ǧumal 'Abi al-Qāsim al-Zağğăğì (unpublished), ed. Muhammad al-Zayn Zarrūq, Ph.D. Dissertation, Mecca, Ğāmi at 'Umm al-qurā.

Ibn Maḍā' al-Qurtubīi, 1366/1947. Kitāb al-Radd 'alā al-nuhāt, ed. Šawqī Dayf, Cairo, Dār al-fikr al-'arabī.

Ibn Mālik, Ğamāl al-dīn Muhammad, 1833. Alfiyya ou la quintessence de la grammaire arabe: publié en original, avec un commentaire, ed. [Antoine-Isaac] Silvestre de Sacy, Paris, Printed for the Oriental Translation Fund of Great Britain and Ireland.

Ibn Mālik, Lāmiyyat al-'af'āl=Ibn Mālik, 1888. La 'Alfiyyah d'Ibnu-Malik : suivie de la Lâmiyyah du même auteur : avec traduction et notes en français et un lexique des termes techniques, ed. A[ntonin] Goguyer, Beirut, Imprimerie des Belles-Lettres.

Ibn Mālik, Gamāl al-dīn 'Abū 'Abd Allāh Muhammad b. 'Abd Allāh al-Ṭā'ī al-Ğayyānī, 1402/1982. Šarh al-Kāfiya al-šăfiya, ed. 'Abd al-Mun im 'Aḥmad Harīdī, Mecca, Dār al-ma' mūn li-l-turāt, 5 vol.

Ibn Mālik, Ğamāl al-dīn Muhammad b. 'Abd Allāh b. 'Abd Allāh al-Ṭā'̄ì al-Ğayyān̄̄ al'Andalusīi, 1410/1990. Šarh al-Tashìl, eds. 'Abd al-Raḥmān al-Sayyid and Muḥammad Badawī al-Mahtūn, Cairo, Hağr, 2 vol.

Ibn Mālik, Gamāl al-dīn Muhammad, 1397/1977. Šarh 'Umdat al-ḥāfiz wa-'uddat al-lāfiz, ed. 'Adnān 'Abd al-Raḥmān al-Dūrī, Baghdad, Wizārat al-'awqāif. 
Ibn Mālik, 1387/1967. Tashīl al-fawā’id wa-takmīl al-maqāṣid, ed. Muhammad Kāmil Barakāt, Cairo, Dār al-kutub al-'arabī.

Ibn Mu'tī, 1900. Die Alfije des Ibn Mu'țî: nach den Handschriften von Berlin, Escorial und Leiden, ed. Karl Vilhelm Zetterstéen, Leipzig, Hinrichs.

Ibn al-Muwaffaq al-Lurqī, 1398/1978. Al-Mabāhit al-kāmiliyya: šarh al-Muqaddima alĞazūliyya (unpublished), ed. Ša 'bān 'Abd al-Wahhāb Muḥammad, Ph.D. Dissertation, Cairo, Gāmi at al-Qāhira, 2 vol.

Ibn al-Qūtịyya, Kitāb al-'Af'âl = 'Abū Bakr Muhammad b. 'Umar b. 'Abd al- 'Azīz b. alQūtiyya, 1894. Il libro dei verbi, ed. Ignazio Guidi, Leiden, Brill.

Ibn al-Sīd al-Bațalyawsī, 'Abū Muhammad 'Abd Allāh b. Muhammad, 1400/1980. Kitāb al-Hulal fì 'Ișlāh al-halal min kitāb al-Ğumal, ed. Sa '̄̄d 'Abd al-Karīm Sa 'ùd̄̄, Baghdad, Wizārat al-țaqāfa wa-l-'i 'lām.

Ibn al-Sīd al-Bațalyawsī, 1398/1979. Kitāb al-Hulal fì šarh 'abyāt al-Ǧumal, ed. Mușțafā 'Imām, Cairo, al-Dār al-mișriyya li-l-țibā' a wa-l-našr wa-l-tawzī' .

Ibn Sīda, Šarh 'abyāt al-Ǧumal = 'Āmūdī 1990.

Ibn 'Usfür al-'Išbīîi, 1970. Al-Mumtic fí al-tașrîf, ed. Faḩr al-dīn Qabāwa, Aleppo, alMaktaba al-'arabiyya, 2 vol.

Ibn 'Ușfūr, 'Alī b. Mu' min, 1392/1972. Al-Muqarrib, eds. 'Ahmad 'Abd al-Sattār alĞawārī and 'Abd Allāh al-Gubūrī, Baghdad, Dīwān al-' awqāe, 2 vol.

Ibn 'Ușfür, 'Alī b. Mu'min b. Muḥammad, 1407/1987. Al-Muțul 'alā kitāb al-Muqarrib fì al-naḥw, ed. Fathiyya Tawfīq Șalāh, Riyadh, F.T. Șalāḥ.

Ibn 'Ușfừr al-'Išbīlì, 1400-1402/1980-1982. Šarh Ğumal al-Zăğḡăği: al-šarh al-kabīr, ed. Șāhị 'Abū Ganāḥ, Baghdad, Wizārat al-'awqāf wa-l-šu'ūn al-dīniyya, 2 vol.

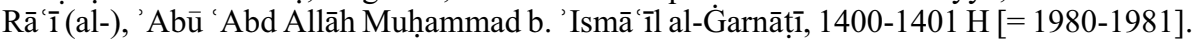
Al-'Ağwiba al-murdiya 'an al-'as'ila al-nahwiyya (unpublished), ed. Salāma 'Abd alQādir al-Murāqī, Master Dissertation, Mecca, Gāmi at 'Umm al-qurā.

Rā'i (al-), Muḥammad b. Muḥammad b. Muhammad b. 'Ismā'îl, 1405/1985. 'Unwān al'ifāda li-'iḩwān al-istifāda (unpublished), ed. Sulaymān Tāğ al-dīn 'Ahmad, Master Dissertation, Mecca, Gāmi 'at 'Umm al-qurā.

Šalawbīn= Šalawbīnī (al-), 'Abū 'Alī, 1393/1973. Al-Tawṭi'a, ed. Yūsuf 'Aḥmad alMuțawwi', Cairo, Dār al-turāt al-'arabī.

Suhaylī (al-), 'Abū al-Qāsim 'Ā̄d al-Rahmān b. 'Abd Allāh al-'Andalusī, 1389/1969. 'Amāli al-Suhaylífi al-nawh wa-l-lugia wa-l-hadịtwa-l-fiqh, ed. Muhammad 'Ibrāhīm alBannā, Cairo, Mața' at al-sa'āda.

Suhaylī (al-), 'Abū al-Qāsim, 1989. Masā’il fì al-nahw wa-l-lugia wa-l-hadịt wa-l-fiqh, ed. Țāhā Muhsin, al-Mawrid 18/3, 84-110.

Suhaylī (al-), 'Abū al-Qāsim 'Abd al-Raḥmān b. 'Abd Allāh, 1398/1978. Natā'iğ al-fikr fì al-naḥw, ed. Muhammad 'Ibrāhīm al-Bannā, Benghazi, Manšūrāt Ğāmi 'at Qāryūnus.

Suyūṭī, Buǵgya = Ğalāl al-dīn 'Abū al-Faḍl 'Abd al-Raḥmān b. 'Abī Bakr b. Muhammad al-

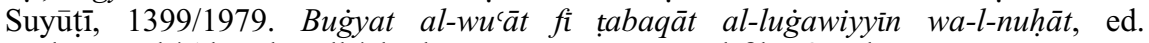
Muhammad 'Abū al-Faḍl 'Ibrāhīm, Damascus, Dār al-fikr, 2 vol.

'Ubbad̄ì̄, Šarh al-Ğazūliyya, vol. 1 = Ġāmidī (al-), Sa'd b. Hamdān Muhammad, 1405$1406 \mathrm{H}$ [= 1984-1986]. Al-'Ubbadì wa-minhağu-hu fì al-nahw ma'a tahqiqq al-sifr al'awwal min šarhi-hi 'alā al-Ğazūliyya (unpublished), Ph.D. Dissertation, Mecca, Ğāmi'at 'Umm al-qurā.

'Ubbadīi, Šarh al-Ğazūliyya, vol. 2 = 'Ubbadīi (al-), 'Abū al-Ḥasan 'Alī b. Muḥammad, 1423$1424 \mathrm{H}[=2003-2004]$. Šarh al-Ğazūliyya (unpublished), eds. Sa '̄̄d b. Mušabbab b. Hasan 'Āl 'Ișām al-' Asmarī (part 1), Hasan b. Naffā ' b. Nuwayfi' al-Ğābirī al-Harbī (part 2), Mu 'tād b. Mu 'tiq b. 'Āqil al-Harbī (part 3), and Muhammad b. Ğamal b. 'Aḥmad al-Kinān̄̄ al-Zahrān̄̄ (part 4), Master Dissertations, Mecca, Gāmi ' at 'Umm al-qurā, 4 vol.

Zubaydī (al-), 'Abū Bakr, 1890. Kitāb al-Istidrāk 'alā Sïbawayhi fì kitāb al-'Abniya wa-lziyādāt 'alā mā 'awrada-hu fi-hi muhaddaban, ed. Ignazio Guidi, Rome, Tipografia della R. Accademia dei Lincei.

Zubaydī (al-), 'Abū Bakr, 1382/1962. Kitāb al-Wädih, ed. 'Abd al-Karīm Hualīfa, Amman, Mațābi' al-ğam 'iyya al-malikiyya al-'ilmiyya. 


\section{Secondary Sources}

'Abd âl-Ğawwād, Samīr 'Ahmad, 1991. Al-’Ubbadī al-nahwīi, Cairo, Dār al-fikr al-'arabī. 'Abū Ğanāḥ, Șāḥib, 1977. "Ibn al-Sīd al-Baṭalyawsī: ḥayātu-hu, manhağu-hu fĩ al-lugga wa1-nahw, ši 'ru-hu", al-Mawrid 6/1, 79-116.

'Afğānī (al-), Sa '̄id, 1951. Fì 'ușūl al-nahww, Damascus, Maṭba at al-Ǧāmi'a al-sūriyya.

- 1957. Min ta'rīh al-nahw: ta'rīh wa-nușuss, Beirut, Dār ail-fikr.

'Āmūdī (al-), Maḥmūd Muhammad 'Ahmad, 1990. Šurūh al-šawāhid al-nahwiyya: dirāsa lugawiyya wa-tahlìliyya ma'a tahqiq Šarh 'abyāt al-Ğumal li-Ibn Sïda (unpublished), Ph.D. Dissertation, Cairo, Ğāmi at 'Ayn Šams, 2 vol.

Arias, Juan Pablo, 1995a. "Gramáticos en al-Andalus (siglo VI H./XIIC.)", al-Andalus Magreb 3, 127-142.

- 1995b. "Ideas sobre la sinonimia en dos sabios andalusíes del siglo VI/XII: al-Suhaylī y al-Šarī̌š̄”, Miscelánea de Estudios Árabes y Hebraicos, Sección Árabe-Islam 44, 7-24.

— 1996. "De los nombres propios, según al-Suhaylī (m. 518 [sic]/1185-6)", Miscelánea de Estudios Árabes y Hebraicos, Sección Árabe-Islam 45, 25-34.

- 2008. "Fuengirola en la historia merced a un gramático: Abu 1-Qasim al-Suhayli", Jábega 97, 70-74.

'Arīnī (al-), Yūsuf b. 'Alī b. 'Ibrāhīm, 1995. Al-Hayāt al-ilmiyya fì al-'Andalus fì 'așr almuwahhidin, Riyadh, Maktabat al-malik 'Abd al-'Azīz al-'āmma.

Arnaldez, Roger, 1956. Grammaire et théologie chez Ibn Hazm de Cordoue, Paris, Librairie Philosophique J. Vrin.

'Azzāwī (al-), Ni 'ma Raḥīm, 1975a. 'Abū Bakr al-Zubaydì al-'Andalusī wa-'ațaru-hu fì alnahw wa-l-luga, Najaf, s.n.

— 1975b. "Taṣwìb mā waqa a min taṣhīf wa-taḥīf fī kitāb al-Istidrāk 'alā Sībawayhi li-' Abī Bakr al-Zubaydī", al-Mawrid 4/1, 251-253.

Baalbaki, Ramzi, 1999. "Expanding the ma'nawì 'awāmil: Suhaylī's innovative approach to the theory of regimen", Al-Abhath 47, 23-58.

- 2008. The Legacy of the Kitāb: Sibawayhi's Analytical Methods within the Context of the Arabic Grammatical Theory, Leiden/Boston, Brill.

Bannā (al-), Muhammad 'Ibrāhīm, 1980. 'Abū al-Husayn Ibn al-Ṭarāwa wa-'ațaru-hu fí alnaḥw, Cairo, Dār al-i 'tișām.

- 1985. 'Abū al-Qāsim al-Suhaylì wa-maḍhabu-hu al-nahwī, Jeddah, Dār al-bayān al'arabī.

Bergter, Annette, 1988. Das Kapitel inna wa-ahawātuhā aus dem "Manhağ as-sālik" des Grammatikers Abū Hayyān al-Ġarnāṭi (1256-1344), Hildesheim/Zürich/New York, Georg Olms Verlag.

Biblioteca de al-Andalus = Lirola Delgado, Jorge et Puerta Vílchez, José Miguel (eds.), 2004-2012. Biblioteca de al-Andalus, Almería, Fundación Ibn Tufayl de Estudios Árabes, 9 vol.

Binaghi, Francesco, 2015. La postérité andalouse du Ğumal d'al-Zağğāğì (unpublished), Ph.D. Dissertation, Aix-en-Provence, Université d'Aix-Marseille.

Bišrī (al-), Sa d 'Abd Allāh Șāliḥ, 1993. Al-Hayāt al-cilmiyya fì 'așr mulūk al-țawā’if fì al'Andalus: 422-488 h./1030-1095 m., [Riyadh], Markaz al-malik Fayṣal li-l-buhụu wa-1dirāsāt al-' islāmiyya.

- 1997. Al-Hayāt al-'ilmiyya fí 'așr al-hilāfa fí al-'Andalus (316 h.-422 h./928 m.-1030 m.), Mecca, Ğāmi 'at 'Umm al-qurā.

Bouvat, Lucien, 1907. "Une grammaire turque du huitième siècle de l'Hegire: La Pénétration dans la langue des Turcs d'Aboû Hayyân al-Gharnatîn”, Actes du XIVe Congrès International des Orientalistes, Alger 1905, Troisième partie: Langues musulmanes (arabe, persan et turc), Paris, Ernest Leroux, 44-78.

Buendía, Pedro, 2015. "Ibn Sīdah y el sexo : en torno al vocabulario de índole sexual en el Kitāb al-Muhașșas (s. XI)", Arabica 62/2-3, 328-360.

Cabanelas [Rodríguez], Darío, 1961. "El Mujașșaṣ de Ibn Sīda de Murcia, primer diccionario de ideas afines en el Occidente musulmán", Miscelánea de Estudios Árabes y Hebraicos 10, 7-36. 
- 1966. Ibn Sida de Murcia, Granada, Universidad de Granada.

Campanelli, Marta, 2015. "Riforma e semplificazione della tradizione linguistica araba: Ibn Maḍā' al-Qurțubī e le prime contestazioni del metodo dei grammatici", Arioli, Angelo (ed.), Miscellanea Arabica 2015, Ariccia, Aracne, 43-60.

- 2016. Complessità e Astrattezza della Tradizione Linguistica Araba: La Teoria della Reggenza e la Contestazione di Ibn Madāa al-Qurțubi (unpublished), Ph.D. Dissertation, Rome, University of Rome La Sapienza.

— 2018. "Verso la semplificazione della grammatica araba: l'analisi linguistica di Ibn Maḍā al-Qurțubî', Miranda, Marina (ed.), Dal Medio all'Estremo Oriente: Studi del Dottorato di ricerca in Civiltà dell'Asia e dell'Africa, Rome, Carocci editore, 49-62.

Carter, Michael G., 2011. "The Andalusian Grammarians, are they different?", Orfali, Bilal (ed.), In the Shadow of Arabic: The Centrality of Language to Arabic Culture. Studies presented to Ramzi Baalbaki on the Occasion of His Sixtieth Birthday, Leiden/Boston, Brill, 31-48.

Cassarino, Mirella and Ghersetti, Antonella, 2017. "Which differences? Notes for a project on Sicilian and Andalusian grammarians", Journal of Arabic and Islamic Studies 17, 67-78.

Dannā' (al-), Muhammad Halīfa, 2003. Lamahāt min ta'rịh tatawwur al-nahw al-'arabì bi-l'Andalus fì daw' Kitāb Sỉbawayhi wa-šurūhi-hi, Beirut, Dār al-multaqā.

Dayf, Šawqī, 1968. Al-Madāris al-nahwiyya, Cairo, Dār al-ma'ārif.

- 1986. Taysir al-nahww al-taclìmi qadìman wa-ḥadịtan, ma'a nahğ tağdìdi-hi, Cairo, Dār alma'ārif.

Deheidel, Dalal, 2002. "El gramático andalusí Muḥammad ben Yahyā al-Rabāḥ̂̄", Miscelánea de Estudios Árabes y Hebraicos, Sección Árabe-Islam 51, 3-17.

- 2003. "Sobre el principio de causalidad (cilal) en la gramática árabe", Miscelánea de Estudios Árabes y Hebraicos, Sección Árabe-Islam 52, 95-103.

Demir, İsmail, 2002. “İbn Mu'tî, eserleri ve nahv'e getirdiği yenilikler”, Atatürk Üniversitesi Illahiyat Fakültesi Dergisi 17, 187-210.

Ditters, Everhard, 1985. "The structure of the mașdar-nounphrase according to 'Abu Hayyān al-'Andalusī”, Zeitschrift für Arabische Linguistik 15, 67-79.

Domingues, José Garcia, 1958. "Filólogos luso-árabes", Boletim de Filologia 17, 184-192.

$E I^{2}=$ Bearman, Peri et al. (ed.), 1960-2005. Encyclopaedia of Islam, $2^{\text {nd }}$ ed., Leiden, Brill, 12 vol.

Elamrani-Jamal, Abdelali, 1979. "Les rapports de la logique et de la grammaire d'après le Kitāb al Masā’il d'al-Bațalyūsī (444-521 = 1052-1127)", Arabica 26/1, 76-89.

- 1983. Logique aristotélicienne et grammaire arabe (étude et documents), Paris, Librairie Philosophique J. Vrin.

- 1985. "La question du nom et du nommé (al-ism wa-l-musammā) entre la dialectique et la grammaire: à propos d'une épitre d'al-Bațalyūsi", Zeitschrift für Arabische Linguistik $15,80-93$.

- 1990. "Verbe, copule, nom dérivé (fil, kalima, ism muštaqq) dans les commentaires arabes du Peri Hermeneias d'Aristote (avec un texte inédit d'Ibn Rušd)", Versteegh, Kees and Carter, Michael G. (eds.), Studies in the History of Arabic Grammar II: Proceedings of the 2nd Symposium on the History of Arabic Grammar, Nijmegen, 27 April-1 May 1987, Amsterdam/Philadelphia, John Benjamins, 151-164.

- 1996. "Ibn al-Sīd al-Bațalyūsī et l'enseignement d'al-Fārāb̄̄”, Bulletin d'études orientales 48, 155-164.

Epalza, Mikel de, 1981. "Notas sobre el lingüista Ibn Sídah y la historia de Denia y su région en el siglo XI", Revista del Instituto de Estudios Alicantinos 33, 161-172.

Ermers, Robert, 1990. "Abū Hayyān al-Andalusī en zijn grammatica van het Turks: Een Introductie", Sharqiyyât 2, 302-323.

- 1995. Turkic Forms in Arabic Structures: The Description of Turkic by Arabic Grammarians (unpublished), Ph.D. Dissertation, Nijmegen, Katholieke Universiteit Nijmegen. 
- 1999. Arabic Grammar of Turkic: The Arabic Linguistic Model Applied to Foreign Languages \& Translation of 'Abu Hayyan al-'Andalusi's Kitāb al-'Idrāk li-Lisān al'Atrāk, Leiden, Brill.

Fāsī (al-), 'Alāl, 1974. "Sībawayhi wa-l-madrasa al-' andalusiyya al-mag̉ribiyya fī al-naḥw", Da'wat al-haqq 16/8, 132-139.

GAL, G = Brockelmann, Carl, 1898-1902. Geschichte der Arabischen Litteratur, Weimar, Verlag von Emil Felber, 2 vol.

GAL, S = Brockelmann, Carl, 1937-1942. Geschichte der Arabischen Litteratur, Supplementband, Leiden, E. J. Brill, 3 vol.

Ğanābī (al-), Țāriq 'Abd 'Awn, 1984. "Manhağ al-Suhaylī al-nahwī fî̀ 'Amālī-hì", Mağallat 'àdāb al-mustansiriyya 8, 103-138.

GAS = Sezgin, Fuat, 1967-2007. Geschichte des arabischen Schrifttums, Leiden, Brill, 13 vol.

Gille, Christiane, 1995. Das Kapitel al-Mausūl ("Das Relativum”) aus dem Manhağ assālik des Grammatikers Abū Haiyān al-G̈arnāṭi (1256-1344), Hildesheim/New York, Georg Olms Verlag.

Ǧīrī (al-), Muhammad, 2002. "Ibn Malkūn al-nahwī min hilāl mahtūt 'Ị̣̂āh al-minhağ fĩ alğam ' bayna kitābay al-Tanbīh wa-l-Mubhağ", al-Dah̆ā'ir 11-12, 65-76.

Glazer, Sidney, 1941a. "The Alfiyya of Ibn Malik: its importance and place in Arabic grammatical science", The Moslem World 31/3, 274-279.

- 1941b. "The Alfiyya-commentaries of Ibn 'Aqīl and Abū Hayyān", The Moslem World 31/4, 400-408.

- 1942. "A Noteworthy Passage from an Arab Grammatical Text", Journal of the American Oriental Society 62/2, 106-108.

Grand'Henry, Jacques, 2010. "De Baghdad à Cordoue. Une migration de la tradition grammaticale arabe", Entre mer de Chine et mer du Nord. Migration des savoirs, transfert des connaissances, transmission des sagesses de l'Antiquité à nos jours. Cinquièmes Journées de l'Orient, Louvain-la-Neuve, 11-13 mars 2009 (= Res Antiquae 7), Bruxelles, Editions Safran, 119-128.

Grande, Francesco, 2017. "The Arabic Lexicographer Ibn Sīdah and the Notion of Semantic Field", Journal of Arabic and Islamic Studies 17, 415-433.

Guardiola, María Dolores, 1990. "Biografías de andalusíes en dos obras de al-Suyūțī", Molina, Luis (ed.), Estudios onomástico-biográficos de al-Andalus IV, Granada, Consejo Superior de Investigaciones Científicas, 215-324.

Ğubrān, Muhammad Mas'ūd, 2005. Mālik Ibn al-Murahhal, 'adīb al-'udwatayn, Abu Dhabi, al-Mağma' al-țaqāfĩ.

Ğubūrī(al-), 'Imām Hạan, 1991. Al-'Alfiyya bayna Ibn Mu'ți wa-Ibn Mālik: Dirāsa nahwiyya sarfiyya muqārana, Cairo, s.n.

Hadītī (al-), Hadīğa, 1966. 'Abū Hayyān al-Nahwì, Baghdad, Maktabat al-nahḍa.

Ḥağğ̄î, Muhammad, 1974. "Kitāb Sībawayhi fī al-Magrib wa-l-'Andalus”, Da'wat al-ḥaqq $16 / 7,160-164$.

Hamzé, Hassan, 2002. "Logique et grammaire arabe dans l'œuvre d'Averroès", Khoury, Raif Georges (ed.), Averroes (1126-1198): oder der Triumph des Rationalismus. Internationales Symposium anlässlich des 800. Todestages des islamischen Philosophen, Heidelberg, 7.-11. Oktober 1998, Heidelberg, Universitätsverlag C. Winter, 157-174.

Huațīb (al-), 'Abd al-Lațîf Muḥammad, 1999. 'Abū Hayyān al-'Andalusĩ: al-nahwì almufassir, Damascus, Dār Ibn Katīr.

Haytī (al-), 'Abd al-Qādir Rahīm, 1975. Hașāis iṣ madhab al-'Andalus al-nahwī hilāl al-qarn al-sābic al-hiğrī, Baghdad, Dār al-qādisiyya.

Hiğāzī, Mahmūd Fahmī, 1995. "Dawr rihlat Muhammad b. Yahyā al-Rabāhī 'ilā Mișr fī ta'sīs al-dirāsāt al-naḥwiyya bi-1-'Andalus", Revista del Instituto Egipcio de Estudios Islámicos 27, 121-140.

Humbert, Geneviève, 1994. "Le Kitāb de Sībawayhi d'après l'autographe d'un grammairien andalou du XII siècle", Binebine, Ahmed-Chouqui (ed.), Le manuscrit arabe et la codicologie, Rabat, Publications de la Faculté des Lettres et des Sciences Humaines, $9-20$. 
- 1995. Les voies de la transmission du Kitāb de Sïbawayhi, Leiden/New York/Köln, Brill.

Ibn Šarīfa, Muhammad, 1996. Ibn Harìq al-Balansĩ: hayātu-hu wa-'ātāaru-hu, Casablanca, Maṭa at al-nağāh al-ğadīda.

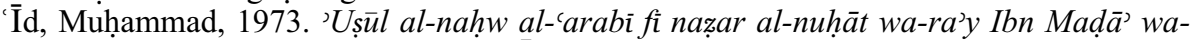
daw' 'ilm al-luga al-hadit, Cairo, 'Ālam al-kutub.

Kasher, Almog, 2016. "Iconicity in Arabic Grammatical Tradition: Al-Suhaylī on the Correspondence Between Form and Meaning", Romano-Arabica 16, 201-224.

Lancioni, Giuliano, 1996. "Rhetoric and Ideology in Abu Hayyan's Kitāb al-'Idrāk", The Arabist: Budapest Studies in Arabic 17, 105-119.

Larcher, Pierre, 1996. Compte-rendu de Šarh al-Tashīl de Ğamāl al-dīn Muhammad Ibn Mālik, éd. 'Abd al-Rahmān al-Sayyid et Muhammad al-Mahtūn, 4 parties en 2 vol., Gizeh, Hağar, 1410/1990, Arabica 43/3, 506-509.

- 2011. "Khabar/inshā', une fois encore", Orfali, Bilal (ed.), In the Shadow of Arabic: The Centrality of Language to Arabic Culture. Studies presented to Ramzi Baalbaki on the Occasion of His Sixtieth Birthday, Leiden/Boston, Brill, 49-70.

Māğid, Ğa far, 1969. "Lablī, philologue andalou du VII/XIIe s.", Revue de l'Institut des Belles Lettres Arabes 123, 103-117.

Mațar, 'Abd al-'Azīz, 1974. Minhağ Ibn Hišām al-Lahmì fì al-istidlāl bi-'ārā' Sỉbawayhi, Doha, s.n.

Molina Rueda, Beatriz, 1987. "Ibn Maḍā' al-Qurtubī: su concepción de las 'causas' gramaticales ('ilal)", Miscelánea de Estudios Árabes y Hebraicos 36, 225-235.

Muḥȳ̄ al-dīn, Māğid Kāmil, 2001. Ibn al-Sìd al-Bațalyawsī, Cairo, al-Hay’a al-mișriyya al'āmma li-l-kitāb.

Mursī, Muhammad Șafwat, 1987. Šurūh al-'aClām li-'Alfiyyat al-'imām Ibn Mālik, Ǧamāl aldīn Muhammad b. 'Abd Allāh Ibn Mālik al-'Andalusī, Cairo, Mața 'at Hassān.

Mutlaq, 'Albīr Habīb, 1967. Al-Haraka al-lugawiyya fi al-'Andalus mundu al-fath al-'arabi hattā nihāyat 'așr mulūk al-țawā'if, Sidon/Beirut, al-Maktaba al-'așriyya.

Nağğāa (al-), Šarīf 'Abd al-Karīm, 2009. “'Abū al-Hasan Ibn al-'Ahḍar al-'Iš̉bīlī wa-'ārā'u-hu fī al-naḥw wa-l-luğa”, Mağallat ğāmi'at 'Umm al-Qurā li-‘ulūm al-lug̀āt wa-'āāābi-hā 2, 11110 .

Nağīb, Maḥmūd 'Abd al-Karīm, 2000. Muঙ̌ğam al-šawāhid al-nahwiyya fì šurūh 'Alfiyyat Ibn Mālik wa-hawā̄ši-hā al-natriyya wa-l-šíriyya, Damascus, Maktabat dār al-Fārābī.

— 2005. "Ibn Mālik al-Ṭā'ī nāẓim 'ulūm al-'arabiyya", al-Turāt al-'Arabì 25, 211-229.

Nakamura, Kōjirō, 1974. "Ibn Maḍā's criticism of Arabic grammarians", Orient 10, 89-113.

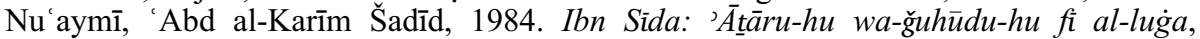
Baghdad, Wizārat al-țaqāfa wa-l' i 'lām.

Peña Martín, Salvador, 1987. La obra lingüistica y filológica de Ibn al-Sìd al-Bațalyawsĩ: Teoría y método de las ciencias árabes islámicas del lenguaje y el texto a través de un especialista del siglo V-VIH. / XI-XIIC. (unpublished), Ph.D. Dissertation, Granada, Universidad de Granada.

- 1991. "Gramáticos en al-'Andalus: d'Ibn Sīdah al-Mursī a Ibn al-Sīd al-Bațalyawsî̀”, Sharq al-Andalus 8, 43-53.

- 1993-1994. "El tratado de la frase por ibn al-Sīd al-Bațalyawsī”, Miscelánea de Estudios Árabes y Hebraicos 42-43, 203-218.

- 2004. "El signo en la lingüística árabe medieval", Analecta Malacitana 11, 131-181.

— 2005a. "Abū 'Alī al-Qālì, de Bagdad a Córdoba: transmisión o renovación en la filologia árabe”, Monferrer Sala, Juan Pedro and Rodríguez Gómez, María Dolores (eds.), Entre Oriente y Occidente: Ciudades y viajeros en la Edad Media, Granada, Universidad de Granada, 231-242.

- 2005b. "Hermenéutica y gramática bajo los almohades: Ibn Jarūf y los testimonios tardíos", Al-Qanțara 26/2, 371-380.

- 2006. "Gramática y verdad: tiempo y tiempo verbal según Ibn al-Sīd", Anaquel de Estudios Árabes 17, 203-220. 
- 2007. Coran, palabra y verdad: Ibn al-Sid y el humanismo en al-'Andalus, Madrid, Consejo Superior de Investigaciones Científicas.

- 2013. "Which Curiosity? Ibn Hazm's Suspicion of Grammarians", Adang, Camilla, Fierro, Maribel and Schmidtke, Sabine (eds.), Ibn Hazm of Cordoba: The Life and Works of a Controversial Thinker, Leiden/Boston, Brill, 233-250.

Peña [Martín], Salvador and Arias, Juan Pablo, 1993. "Gramáticos árabes en Málaga", Analecta Malacitana 16, 59-79.

- 2009. "Filología, lingüística y buenas letras en Málaga (sobre la contribución andalusí a la obra iniciada en Iraq)", Peña [Martín], Salvador (ed.), Iraq y al-Andalus: Oriente en el Occidente Islámico, Almería, Fundación Ibn Tufayl de Estudios Árabes, 205236.

Qabāwa, Fahr al-dīn, 1999. Ibn 'Ușfür wa-l-tașrīf, Damascus, Dār al-fikr.

Qawzī (al-), 'Awwid b. 'Aḥmad, 1987. "Nuktat al-Nukat fī sariqat al-'A 'lam al-Šantamarī”, Mağallat Mağma' al-luġa al-'arabiyya bi-Dimašq 62, 685-714.

Rāğiḥī (al-), 'Abduh, 1980. Durūs fi šurūh al-'Alfiyya, Beirut, Dār al-nahḍa al-'arabiyya. Ramón Guerrero, Amelina, 1984. El cordobés Ibn Madā' (1119-1196) y la reforma de la gramática árabe, Granada, Universidad de Granada.

Ramón Guerrero, Rafael, 1995. "Influencia d'al-Fārābī en Ibn al-Sīd de Badajoz”, La Ciudad de Dios 208, 51-66.

Rašīd, Bassām Yāsīn, 1982-1986. "Abū 'Alī al-Qālī: vida y obra. Estudio de sus transmisiones lingüístico-literarias", Miscelánea de Estudios Arabes y Hebraicos (I) 31, 17-45; (II) 32-33, 37-54; (III) 34-35, 271-286.

Rodríguez Gómez, Maria Dolores, 1992. "Abū 'Alī al-Šalawbīn: un gramático andalusí de la étapa almohade", Escobedo Rodríguez, Antonio (ed.), Homenaje a la Profesora Elena Pezzi, Granada, Universidad de Granada, 97-104.

Ša 'bān = Ša bān, Muhammad Mahmūd, 1972. Al-'A'lam al-Šantamarī wa-'ațaru-hu fì alnahw ma'a tahqìq kitābi-hi Šarh 'abyāt al-Ğumal (unpublished), Ph.D. Dissertation, Cairo, Gāmi 'at al-'Azhar, 2 vol.

Ša bān, Hāāmid Muhammad 'Amīn, 1984. Al-Buhūt al-lugawiyya fì al-Rawd al-'unuf, [Cairo], Maktabat al-'anğlū al-mișriyya.

Šā ir (al-), Hasan Mūsāē, 1988. "Hațtā̄b al-Māridī wa-minhağu-hu fĩ al-naḥw", Mağallat alĞāmica al-'islāmiyya 79-80, 107-142.

Sarțāwī (al-), Ma'ād, 1988. Ibn Mad̄ā’ al-Qurțubī wa-ğuhūdu-hu al-nahwiyya, Amman, Dār mağdalāwī li-1-našr wa-l-tawzī' .

Šāwiš (al-), 'Abd al-Mu īn 'Alī, 2013. Al-Suhaylĩ: manhağu-hu wa-'ārā'u-hu al-nahwiyya fì kitābi-hi Natā'iğ al-fikr, al-Zāwiya, Ğāmi' at al-Zāwiya.

Sayyid (al-), 'Aḥmad, 1979. "Šarh al-Saffār li-Kitāb Sỉbawayhi”, Mağallat Kulliyyat alluǵa al-carabiyya (Riyadh) 9, 29-5i.

Sayyid (al-), 'Amīn 'Alī, 1964. Al-Ittiğāhāt al-nahwiyya fí al-'Andalus wa-'atataru-hā fì tațwīr al-nahw (unpublished), Ph.D. Dissertation, Cairo, Kulliyyat Dār al-'ulūm.

Sayyid (al-), Sabrī 'Ibrāhīm, 1989. 'I'rāb al-Qur'ān fì Tafsìr 'Abì Hayyān, Alexandria, Dār al-ma rifa al-ğāmi iyya li-1-našr.

Serrano, Delfina, 2002. "Ibn al-Sīd al-Batalyawsī (444/1052-521/1127): de los reinos de taifas a la época almorávide a través de la biografía de un ulema polifacético", $\mathrm{Al}$ Qantara 23/1, 53-92.

- 2008. "Ibn al-Sīd al-Bațalyawsī (1052-1127): un gramático con vocación de filósofo", Jábega 97, 53-61.

Serrano Niza, Dolores, 1999. El proyecto lexicográfico de Ibn Sidah, un sabio en la taifa de Denia, Onda, Ajuntament.

Shareef, Rashed ben Rajeh, 1972. A Critical Edition of Ibn Mālik's al-Kāfiya al-Shāfiya alKubrā, and an Analysis of the Grammatical Method Used in this Work and his Alfiyya (unpublished), Ph.D. Dissertation, University of Cambridge, 2 vol.

Talbi = Ṭālibī (al-), Muḥammad, 1956. Al-Muḩașșaș li-Ibn Sìdah: dirāsa - dalìl, Tunis, alMațba'a al-'aṣriyya. 
Ṭantāwī (al-), Muhammad, 1938. Naš̀at al-naḥw wa-ta'rīh 'ašhar al-nuhāt, Cairo, Dār alșāwī li-l-tab' wa-l-našr wa-l-ta' līf.

Tayyār (al-), Riḍā 'Abd al-Ğalīl, 1980. Al-Dirāsāt al-lugiawiyya fí al-'Andalus mundu mațac al-qarn al-sādis al-hiğrī hattā nihāyat al-qarn al-sābi' al-hiğrì: 'așr al-murābițīn wa-almuwahhidìn, Baghdad, Dār al-rašīd li-l-našr.

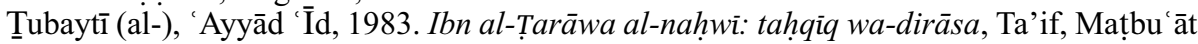
nādī al-Ṭa 'if al-'adabī.

- 1996. "Al-Dars al-naḥwī fĩ al-'Andalus fī al-qarn al-hāmis al-hiğrī”, al-Zaydān, 'Abd Allāh b. 'Alī et al. (eds.), al-Siǧill al-'ilmì li-nadwat al-'Andalus: qurūn min altaqallubāt wa-l-'ațā'āt, al-Qism al-rābi': al-lugia wa-l-'adab, Riyadh, Maṭbū āt maktabat al-malik 'Abd al-'Azīz al-'āmma, 629-642.

- 1998. Ibn Ṭalha al-nahwĩ: hayātu-hu, 'ātāarru-hu, 'ārā'u-hu, Mecca, Maktabat dār al-turāt.

'Umar, 'Ahmad Muhtār, 1967. "Da 'wat al-'iṣlāḥ li-l-naḥw al-'arabī qabla Ibn Maḍā'”, Mağallat al-'Azhar 39, 515-519.

Urvoy, Dominique, 2005. "Le rapport entre adab et falsafa chez Ibn al-Sīd al-Batalyaws $\vec{\imath}$ ", Soravia, Bruna and Sidarus, Adel (eds.), Literatura e cultura no Gharb al-Andalus: Simpósio internacional, Lisboa, Abril de 2000, Lisbon, Instituto de Investigação Científica Tropical, 245-255.

Velázquez Basanta, Fernando Nicolás, 1987-1988. "Abū Ŷa far Ahmad Ibn 'Abd al-Nūr, gramático y poeta malagueño del s. XIII en la Ihāta de Ben al-Jațīb", Estudios de Historia y de Archeología Medievales 7-8, 153-164.

Versteegh, Kees, 1989. "A sociological view of the Arab grammatical tradition: grammarians and their professions", Wexler, Paul, Borg, Alexander and Swmek, Saśwn (eds.), Studia linguistica et orientalia memoriae Haim Blanc Dedicata, Wiesbaden, Otto Harrassowitz, 289-302.

- 1997. Landmarks in Linguistic Thought III: The Arabic Linguistic Tradition, London/ New York, Routledge.

- 2013. "Ibn Madāà as a Zāhirī Grammarian", Adang, Camilla, Fierro, Maribel and Schmidtke, Sabine (eds.), Ibn Hazm of Cordoba: The Life and Works of a Controversial Thinker, Leiden/Boston, Brill, 205-231.

Wadḡīrī (al-), 'Abd al-' 'Ālī, 1978. "Hawla ta'tīr al-Qālī fī al-dirāsāt al-lugagawiyya wa-1'adabiyya bi-l-'Andalus", Mağallat Kulliyyat al-'ādāb wa-l-culūm al-'insāniyya (Fès) 1, 121-141.

- 1983. 'Ab̄u 'Alì al-Qālì wa-'ataru-hu fì al-dirāsāt al-lugiawiyya wa-l-'adabiyya bi-l'Andalus, Rabat, Ministère des Habous et des Affaires Islamiques.

Weipert, Reinhard, 2002. Classical Arabic Philology \& Poetry: A Bibliographical Handbook of Important Editions from 1960 to 2000, Leiden/Boston/Köln, Brill.

Wolfe, Ronald Gary, 1984. Ibn Madā' al-Qurtubi and the "Book in refutation of the Grammarians" (unpublished), Ph.D. Dissertation, Bloomington, Indiana University.

- 1990. "Ibn Maḍā' al-Qurțubī's Kitāb al-Radd 'alā n-Nuhāt: An Historical Misnomer", Versteegh, Kees and Carter, Michael G. (eds.), Studies in the History of Arabic Grammar II: Proceedings of the 2nd Symposium on the History of Arabic Grammar, Nijmegen, 27 April-1 May 1987, Amsterdam/Philadelphia, John Benjamins, 295-304.

Yāḡì', Hāšim, 2008. 'Abu 'Ali al-Qālì: hayātu-hu wa-'ātārru-hu, Amman, Dār Ibn al-Ğawzī.

Yāsīn, 'Ayman Hišām, 2015. Al-Dars al-nahwìifí al-'Andalus min al-qarn al-sādis hattā nihāyat al-qarn al-țāmin al-hiğriyyayn, Damascus, al-Hay'a al-'āmma al-sūriyya li-l-kitāb.

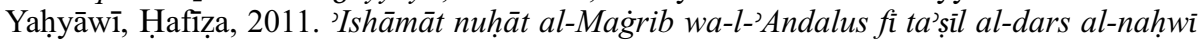
al-'arabì hilāl al-qarnayn al-sādis wa-l-sābic al-hiğriyyayn, Tizi Ouzou, Manšūrāt mahbar al-mumārasāt al-lugàwiyya fî al-Ğazā' ir.

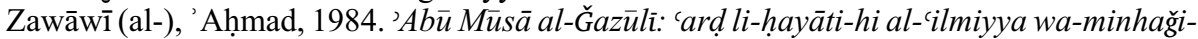
hi fi al-baht wa-ta'tiri-hi fì haql al-nahww, țumma naqd li-minhaği-hi, Mohammedia, Maṭba at Mūnāstīr. 